\title{
Study of a Solar PV-Wind-Battery Hybrid Power System for a Remotely Located Region in the Southern Algerian Sahara: Case of Refrigeration
}

\author{
Maamar Laidi ${ }^{1,2, *}$, Salah Hanini ${ }^{2, *}$, Brahim Abbad ${ }^{1}$, Nachida Kasbadji Merzouk ${ }^{1}$ and \\ Mohamed Abbas'
}

${ }^{1}$ FTEER/FCER, Solar Equipment Development Unit (UDES) of Bou Ismail Tipasa, Algeria

${ }^{2} L M B P T$, Dr. Yahia Fares University of Médéa, Algeria

\begin{abstract}
The present work shows an experimental investigation that uses a combination of solar and wind energy as hybrid system (HPS) for electrical generation under the Algerian Sahara area. The generated electricity has been utilized mainly for cooling and freezing. The system has also integrated a gasoline generator to be more reliable. This system is not linked with conventional energy and is not fixed in one region as it is the case of the military base in the Algerian borders. The cooling load consisted of three containers of $10 \mathrm{~m}^{3}$ each with total electricity consumption of $45 \mathrm{kWh} /$ day, two positive rooms (with an internal temperature of $+2^{\circ} \mathrm{C}$ and an external temperature of $35^{\circ} \mathrm{C}$ ) and one negative room (with an internal temperature of $-20^{\circ} \mathrm{C}$ and an external temperature of $35^{\circ} \mathrm{C}$ ). Measurements included the solar radiation intensity, the ambient temperature and the wind speed was collected from Adrar weather station (a windy place in Algeria) for the year of 2010. To simulate the hybrid power system (HPS) HOMER was used. Emissions and renewable energy generation fraction (RF) of total energy consumption are calculated as the main environmental indicator. The net present cost (NPC) and cost of energy (COE) are calculated for economic evaluation. It is found that, for Adrar climates, the optimum results of HPS show a $50 \%$ reduction of emissions with $47 \%$ of renewable energy fraction.
\end{abstract}

Keywords: Environment, economy, algerian sahara area, hybrid power system, refrigeration, HOMER.

\section{INTRODUCTION}

Since Algeria is a huge country with small villages located in remote and hilly areas and non-permanent military bases established in isolated southern frontiers of Algeria, the grid extension to populations living in such areas is costly and unfeasible. In such situations decentralized renewable energy based power generating options can provide feasible alternatives options. These alternatives may include hybrid power systems like wind-pv-diesel, wind-diesel, pv-diesel and others with or without battery backup option. With continuous research and development efforts, it has been established that the hybrid systems, if optimized properly, are both cost effective and reliable compared to single power source systems. In this study, an attempt is made to design an optimal wind/pv/diesel hybrid power for a refrigeration need to a small military base established in the southern frontiers of Algeria, where the wind speed and solar radiation database were measured at the weather station of the Renewable Energy Research Unit in Saharian Medium (URER/MS) along with other meteorological data for the region of Adrar $\left(27.9^{\circ} \mathrm{N}, 0.3^{\circ} \mathrm{W}, 263 \mathrm{~m}\right)$, Algeria [1]. The main aim of the study is to reduce the diesel consumption and at the same time maintain a

*Address corresponding to these authors at the LMBPT, Dr. Yahia Fares University of Médéa, Algeria; Tel/Fax: (213) 024410200 / 24410133 ; E-mails: maamarw@yahoo.fr, s_hanini2002@yahoo.fr, abbasdreams2003@yahoo.ca continuous supply of power to the inhabitants of the military base. Since big consumption of the generated electricity in houses is mainly conducted to cooling and air conditioning, in this work the load consists of two positive containers (cold rooms) and one negative container (freezing room) with a total daily energy consumption of $45 \mathrm{kWh} /$ day. A schema of the proposed hybrid system is portrayed in Figure 1.

\section{REVIEW}

Several studies related to using HPS as an alternative solution for the conventional energy have been located in the literature. Yang et al. [2] suggested an optimal sizing method to optimize the configurations of a hybrid solar-wind system with battery banks. They used a genetic algorithm (GA) to calculate the optimum system configuration that could achieve the clients required loss of power supply probability (LPSP) with minimum annualized cost of system (ACS).

Moreover, small off-grid standalone hybrid power systems offer an imperative choice for decreasing the electricity gap in remote areas of the developing and developed world, where progress in grid extension stays slower than population growth [3, 4]. According to Celik [5], these small-scale systems, even if generate relatively little power, but can considerably enhance quality of life in remote areas [5]. Cavello and Grubb [6] revealed that $1 \mathrm{kWh}$ of electricity provides ten times 


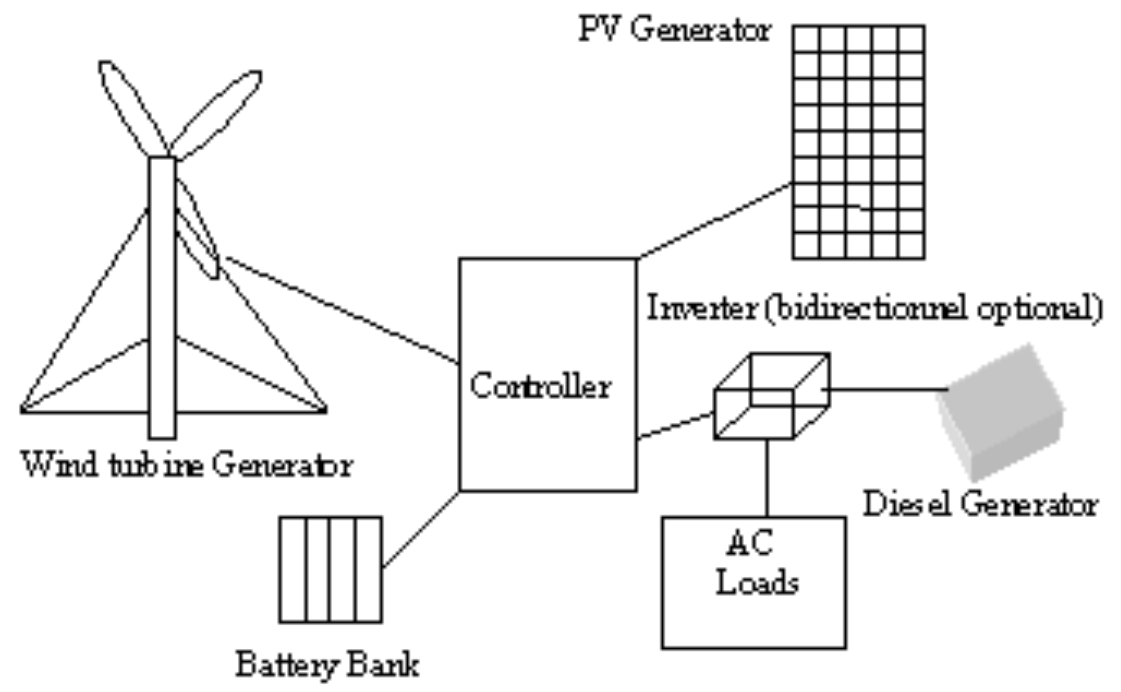

Figure 1: Schematic diagram of hybrid energy system.

more electricity services in India than in Indiana and added that two small wind turbines, which would supply only two homes with electric heating in the United States, could pump water for 4000 people in Morocco [6].

Recently, Djohra Saheb et al. [7] proposed a hybrid power system to generate power for grid connected applications in the southern parts of Algeria. Results showed that it is possible for Algeria to use the solar and wind energy to generate enough power for villages in the desert and rural areas with slightly lower estimation of energy cost and significant decrease in the pollutants emissions. Ekren et al. [8] designed and developed an optimum sizing procedure of wind-pvdiesel hybrid system for small applications in Turkey. Saheb-Koussa [9] designed a wind/pv/diesel hybrid energy system with battery backup and conducted a techno-economical feasibility of the system for remote applications in Algeria. Results indicated that the hybrid system is the best option for all the sites considered, provided higher system performance than photovoltaic or wind alone systems, the reliability of the system improved, and finally it was exposed that the energy cost depends largely on the renewable energy potential. Nfah et. al. [10] studied a solar/diesel/battery hybrid power systems to meet the energy demands of a typical rural domestic in the range $70-300 \mathrm{kWh} / \mathrm{yr}$ and found that a hybrid power system comprising a $1440 \mathrm{Wp}$ solar pv array and a $5 \mathrm{~kW}$ single-phase generator operating at a load factor of $70 \%$, could meet the required load.

Sopian et al. [11] presented the performance of an integrated PV-wind hydrogen energy production system. Their system was able of producing 130-140 $\mathrm{ml} / \mathrm{min}$ of hydrogen, for an average global solar radiation and wind speed ranging between 200-800 $\mathrm{W} / \mathrm{m} 2$ and 2.0- $5.0 \mathrm{~m} / \mathrm{s}$, respectively. Arribas et al. [12] presented the guidelines suitable for long-term assessment hybrid power systems with diverse combinations and also for the assessment of components and of the short-term performance of the systems necessary at the actual stage of development. The study also suggested that, at least for demonstration projects, the monitoring activity should be used not only for long-term assessment, but also for the characterization of components and for the analysis of the system, in order to gain more understanding on hybrid systems. Jose et al. [13] presented a comprehensive techno-economical analysis of an hybrid power system for the production of hydrogen and that the selling price of hydrogen produced by means of electrolysis should be high in order to recover the initial investment of a PV-Wind system in a reasonable lapse of time (ten years).

To meet the energy loads of seawater greenhouse in the Oman, Mahmoudi et al. [14] used hourly wind speed and solar radiation data to design a wind-solar power system. Dufo-Lopez et al. [15] presented a triple multi-objective design of isolated hybrid systems minimizing, simultaneously, the total cost throughout the installation, pollutant emissions $\left(\mathrm{CO}_{2}\right)$ and unmet load. To achieve the task, the authors, used a multiobjective evolutionary algorithm (MOEA) and a genetic algorithm (GA) to find the best combination of components of the hybrid system and control strategies. Tina et al. [16] assessed the long-term performance of a hybrid solar-wind power system for 
both standalone and grid connected applications. Shakya et al. [17] studied the feasibility of standalone hybrid wind-pv system incorporating compressed hydrogen gas storage in Australia.

\section{WIND ENERGY IN ALGERIA}

As seen in Figure 2, Algeria is generally quite windy. $78 \%$ of its surface is characterized by velocities exceeding $3 \mathrm{~m} / \mathrm{s}$ with about $40 \%$ of these speeds are above $5 \mathrm{~m} / \mathrm{s}$. Wind maps show that the highest wind speeds are distributed in the south while the north is generally less windy. It was found also that the southwestern region has a great potential with speeds exceeding $4 \mathrm{~m} / \mathrm{s}$ for the site of Bechar, $5 \mathrm{~m} / \mathrm{s}$ for the site of Tindouf and even above $6 \mathrm{~m} / \mathrm{s}$ for the site of Adrar. The fact that the southwestern region of the country has a significant wind potential can be attributed to two factors: the first is that it is located in an area of pressure difference (wind in the latitudes near $30 \circ \mathrm{N}$ ). The second is that it is close to the Atlantic Ocean (weather disturbances reaches the region with high intensity).

\section{SYSTEM DESCRIPTION}

A HPS generally comprises more than one primary renewable power generation components working in parallel with a secondary non-renewable component as a backup system. This study focuses on a photovoltaicwind- gasoline generator hybrid power system. The system has a component of current converter as well and includes a battery for power storage. Figure $\mathbf{3}$ shows a general configuration of the proposed HPS system.
In this work, a system optimization in terms of technical and economic feasibility is carried out using HOMER. The purpose is to draw the attention to the enormous potential of wind energy in the region of Adrar $\left(27.59^{\circ} \mathrm{N}, 0.11^{\circ} \mathrm{W}\right)$ that can be exploited in collecting further energy than the solar type already installed.

HOMER (hybrid optimization Model for Electric Renewable) software is a user-friendly micropower design tool that simulates and optimizes stand-alone and grid-connected power systems. Recently, it has been used widely in the field of renewable energy [19]. It can be used with any combination of wind turbines, PV arrays, run-of-river hydro power, biomass power, internal combustion engine generators, microturbines, batteries, and hydrogen storage, serving both electric and thermal loads. The advantage of HOMER is that it can involve also all costs such as the initial capital and the maintenance costs including pollution penalties. The simulation considers a one-year time-period using a minimum time-step of $1 \mathrm{~min}$. It performs a sensitivity analysis which can help the analyst to do 'what-if' analyses and to investigate the effects of uncertainty or changes in input variables. The objective of the optimization simulation is to evaluate the economic and technical feasibility for a large number of technology options, while considering variations in technology costs and energy resource availability [20-27].

\section{COMPONENTS DETAILS}

\subsection{Wind Turbine}

This wind turbine is a modified version of the Berge wind power BWC XL1 type which has a rated power of
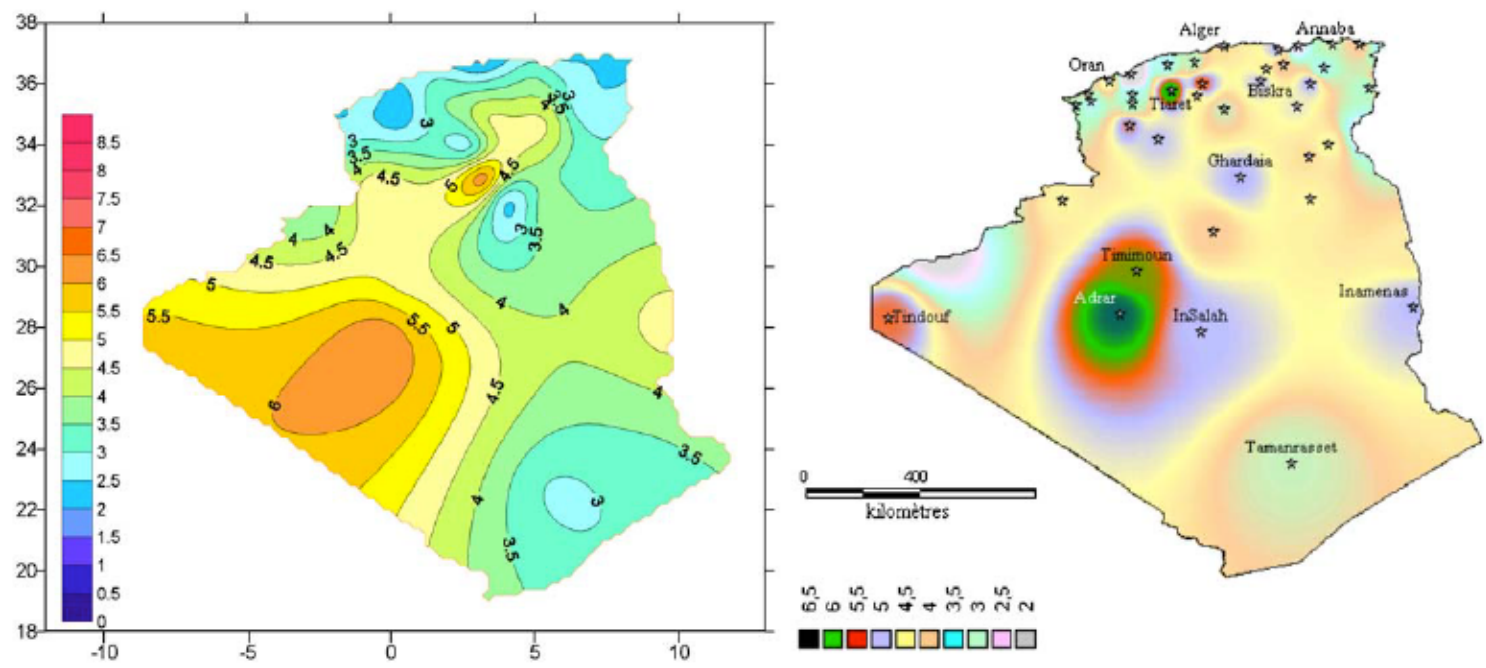

Figure 2: Annual maps of wind speed in Algeria at $10 \mathrm{~m}$ high, [18]. 


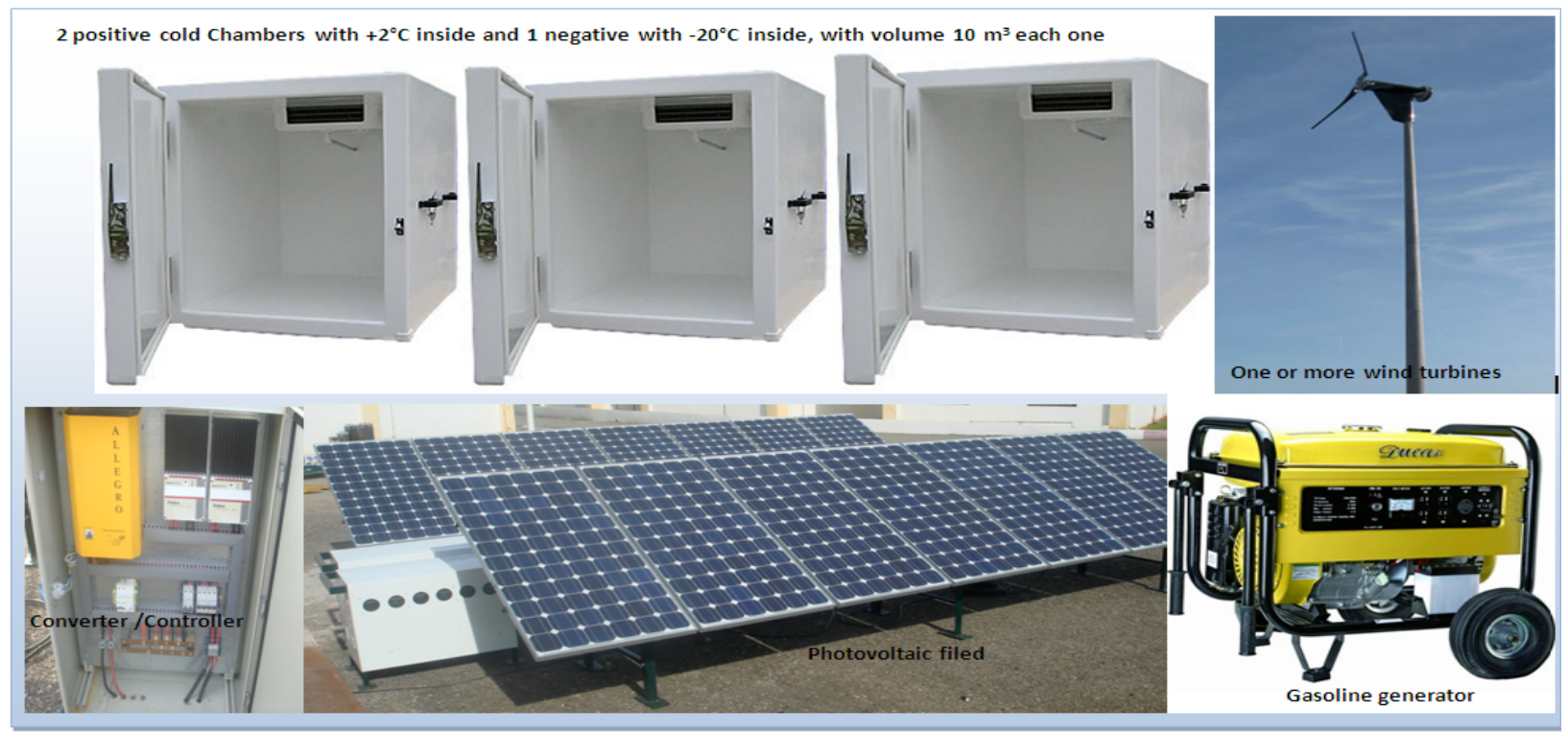

Figure 3: Configuration of the provisional PV/wind/ engine generator as HPS for cooling purposes.

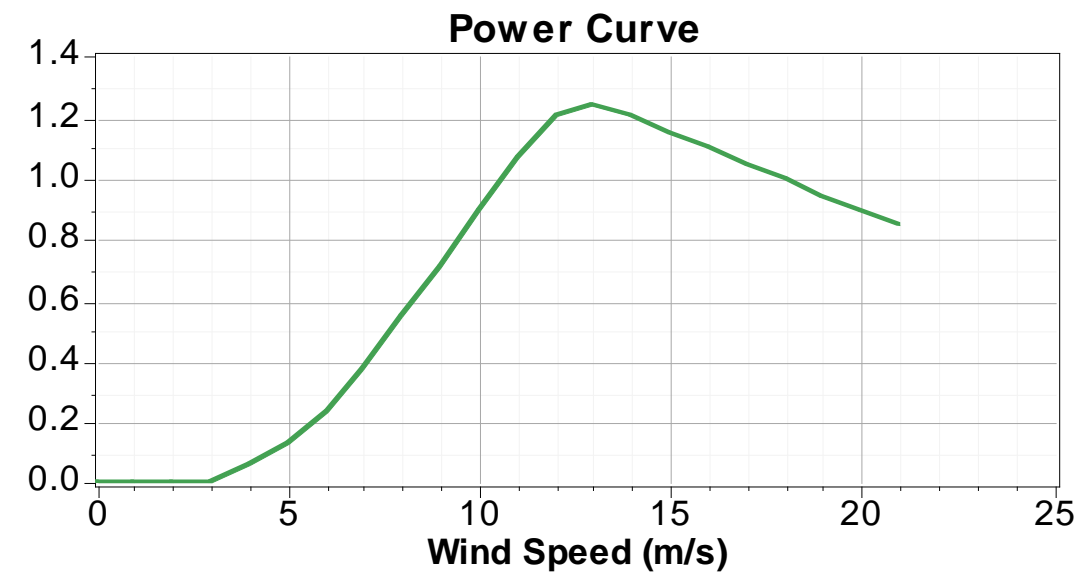

Figure 4: Typical power curve for the BWC XL1 wind turbine.

$1.24 \mathrm{~kW} \mathrm{AC.} \mathrm{It} \mathrm{has} \mathrm{a} \mathrm{lifetime} \mathrm{of} 20$ years with a hub height of $25 \mathrm{~m}$. The typical cost of this turbine is at 3900 \$ with the replacement assumed at the same price and the operation/maintenance $(\mathrm{O} / \mathrm{M})$ costs at $100 \$ / y e a r$. The number of turbines to be used can go up to 4 items. Its performance curve is shown in Figure 4.

\subsection{Gasoline Generator}

This gasoline generator is a $2.6 \mathrm{~kW}$ with a capital cost of $900 \$$ and a lifetime of 5000 operating hours. Again replacement is assumed to be at the same price with the $\mathrm{O} / \mathrm{M}$ costs at $0.04 \$ /$ hour. The fuel price is taken to be constant at $0.2 \$ /$ Litter (Algerian case). To take into consideration any economic effects on the gasoline prices and to assess the effect of this parameters on the system choice, this price has been allowed to vary increasingly up to $0.6 \$ /$ Litter. The efficiency curve is shown in Figure 5.

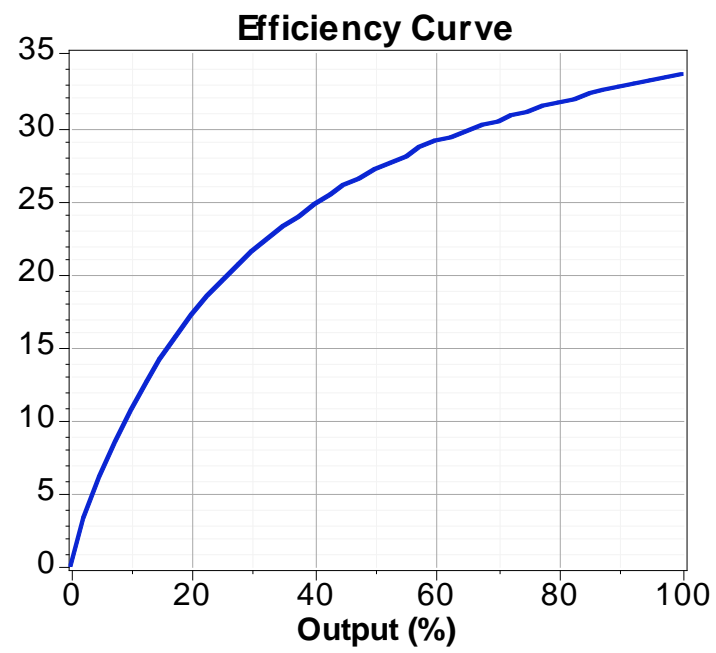

Figure 5: Efficiency curve. 


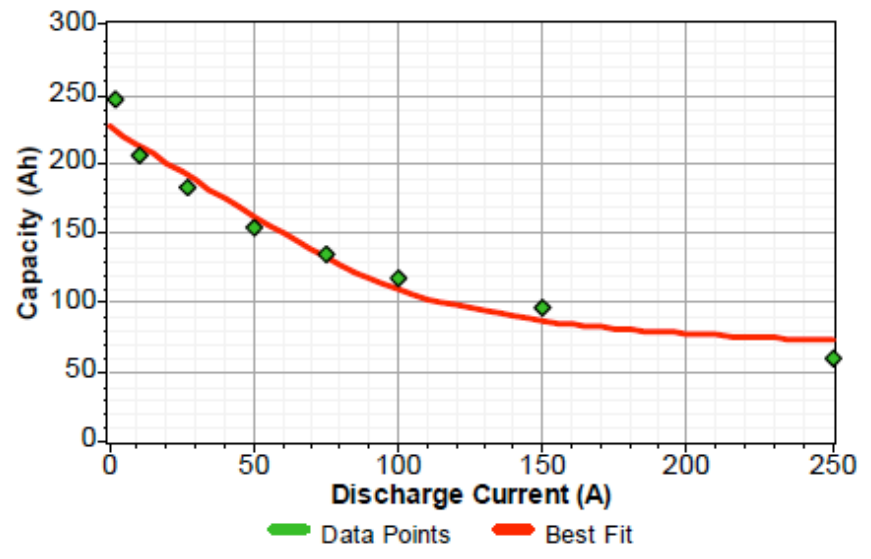

a

Figure 6: The efficiency of the batteries.

\subsection{Batteries System with Controller}

The type of the batteries T-105 of the Torjan battery company (nominal voltage $12 \mathrm{~V}$ of each one with 125 Ah). Their capital cost is at $200 \$$ with a controller charge of the same replacement and $\mathrm{O} / \mathrm{M}$ costs of $45 \$$ year. The number of such a battery can be none or range from 13 to 16 items. The efficiency is shown in Figure 6a-b.

\subsection{Power Converter}

For DC/AC or AC/DC conversion, up to 5 items of 1 kW converter may be used. The capital cost of such a converter is $750 \$$ at the same replacement price and no O/M costs. These have 15-year lifetime and $90 \%$ efficiency.

\subsection{Photovoltaic Arrays}

The photovoltaic array is an expansive component in such a system. The initial cost of photovoltaic arrays is $4000 \$ / \mathrm{kW}$ for Algeria. As to an optimistic system, the costs of installation, replacement and maintenance of a $1 \mathrm{~kW}$ solar energy system are taken as 4,000 $\$$. Sizes of photovoltaic arrays vary $0,1,2,3,4,5,6$ and $7 \mathrm{~kW}$. O/M is $3200 \$ / \mathrm{kW}$. Life time of the modules has been taken as 25 years, these panels are oriented to

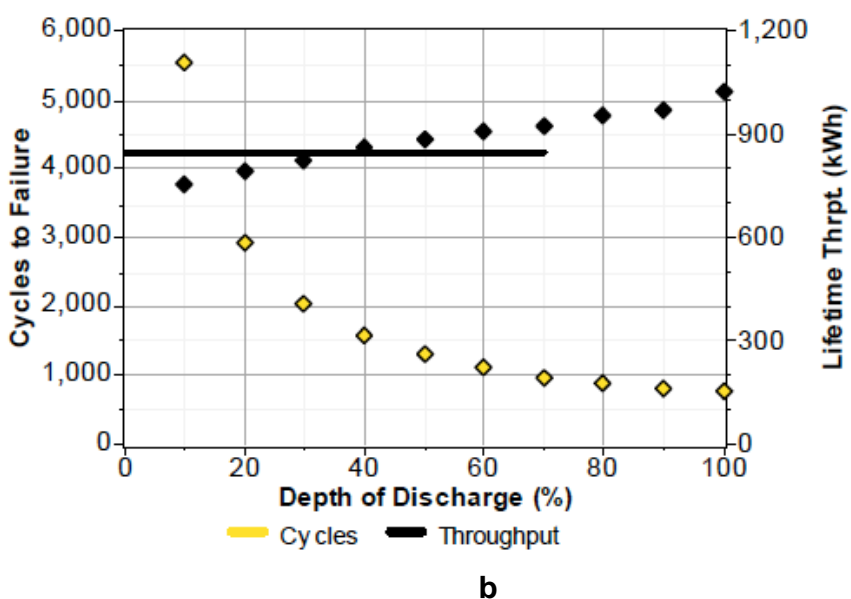

the south with tilted angle equal to the latitude of the region with no tracking mode.

\subsection{Load Profile}

The load demand considered is for one military base refrigeration consumption profile. It is made up of two positive rooms for fruits and vegetables keeping and one negative room for meat freezing. The characteristics of these rooms (containers) are presented in Table 1. As refrigeration is one of the main consuming parts of energy we neglected other parts such as lighting,... etc. This assumption is made on the visit of our team to one of the military base located in Ain-Guezzam/Tammanrasset situated in the frontier between Algeria and Niger.

The seasonal profile is shown in Figure 7. It shows a relatively constant power demand over all months. The annual average daily consumption is at 45 $\mathrm{kWh} /$ day with a peak demand of nearly $3.7 \mathrm{KW}$.

\section{WIND AND SOLAR ENERGY DATA RESOURCE}

The data used in this section are average of wind speed measured at the site of Adrar and collected from the weather station of the Renewable Energy Research Unit in Saharian Medium (URER/MS) which included

Table 1: Positive and Negative Cooling Chambers (Containers) Purposes Characteristics

\begin{tabular}{|c|c|c|c|c|}
\hline & Real volume (m3) & $\begin{array}{l}\text { Electric power (W) } \\
220 \mathrm{~V}\end{array}$ & $\begin{array}{l}\text { Frigorific power } \\
\text { (W) }\end{array}$ & $\begin{array}{c}\text { Average daily } \\
\text { running time }\end{array}$ \\
\hline $\begin{array}{l}\text { Positive cold chamber }(2.40 \times 2.00 \times \\
2.03 \mathrm{~m})\end{array}$ & 9.7 & 980 & 1300 & 12 \\
\hline $\begin{array}{l}\text { Negative cold chamber }(2.40 \times 2.00 \mathrm{x} \\
2.03 \mathrm{~m})\end{array}$ & 9.7 & 1800 & 1200 & 12 \\
\hline
\end{tabular}




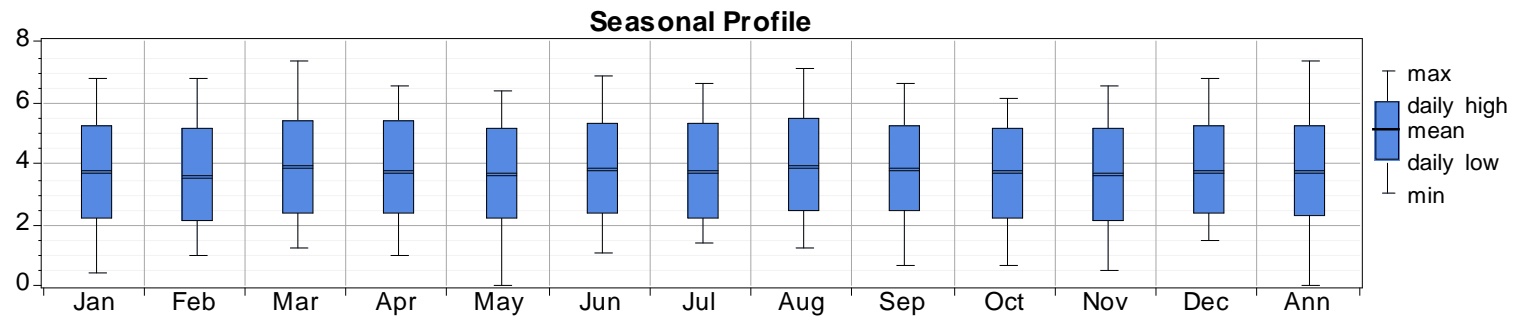

Figure 7: The seasonal profile of the considered load.

the solar radiation intensity, the ambient temperature and the wind speed for the year of 2010 (U.R.E.R). HOMER introduces the clearness index from the location information of the site under investigation (Figure 8-9).

\section{ECONOMICS AND CONSTRAINTS}

The project life time has been considered to be 25 years and the annual interest rate has been taken $10 \%$. As the system has been designed for single military base, the maintenance cost has been taken for
$300 \$ / a n$. There is no capacity shortage for the system and operating reserve is $10 \%$ of hourly load.

Monthly averaged of wind speed are shown in Figure 10. According to this figure, it can be noticed that the importance of the wind potential can ensure the power production when it is cloudy.

\section{OPTIMIZATION RESULTS AND ANALYSIS}

Given the specific wind speed $(6.3 \mathrm{~m} / \mathrm{s})$, solar irradiation $\left(5.9 \mathrm{kWh} / \mathrm{m}^{2} /\right.$ day $)$ and grid electricity price

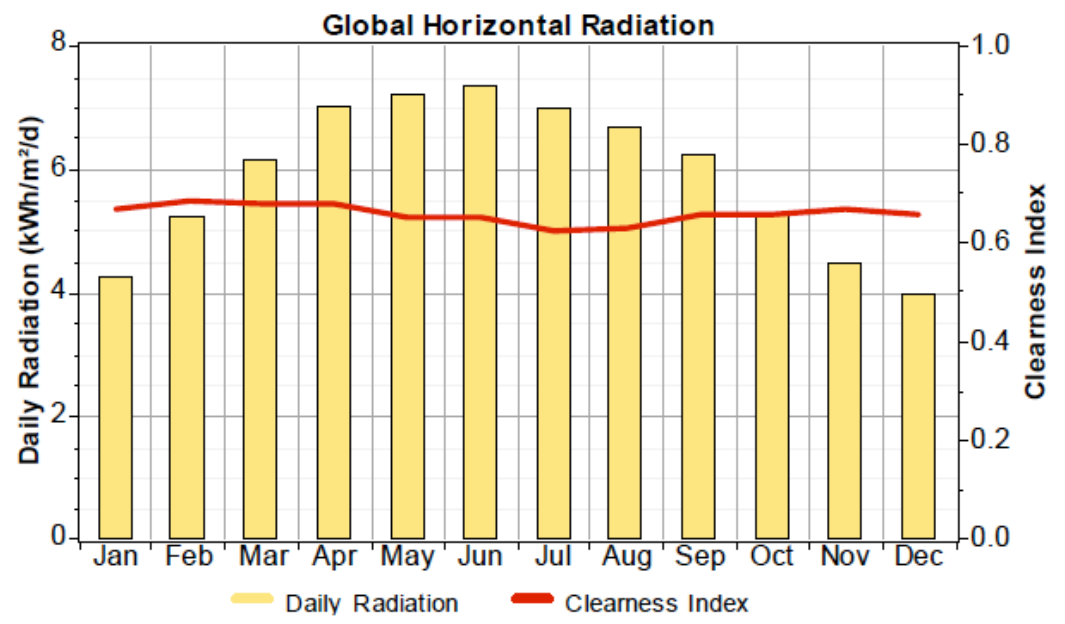

Figure 8: Average daily solar radiation data of Adrar.

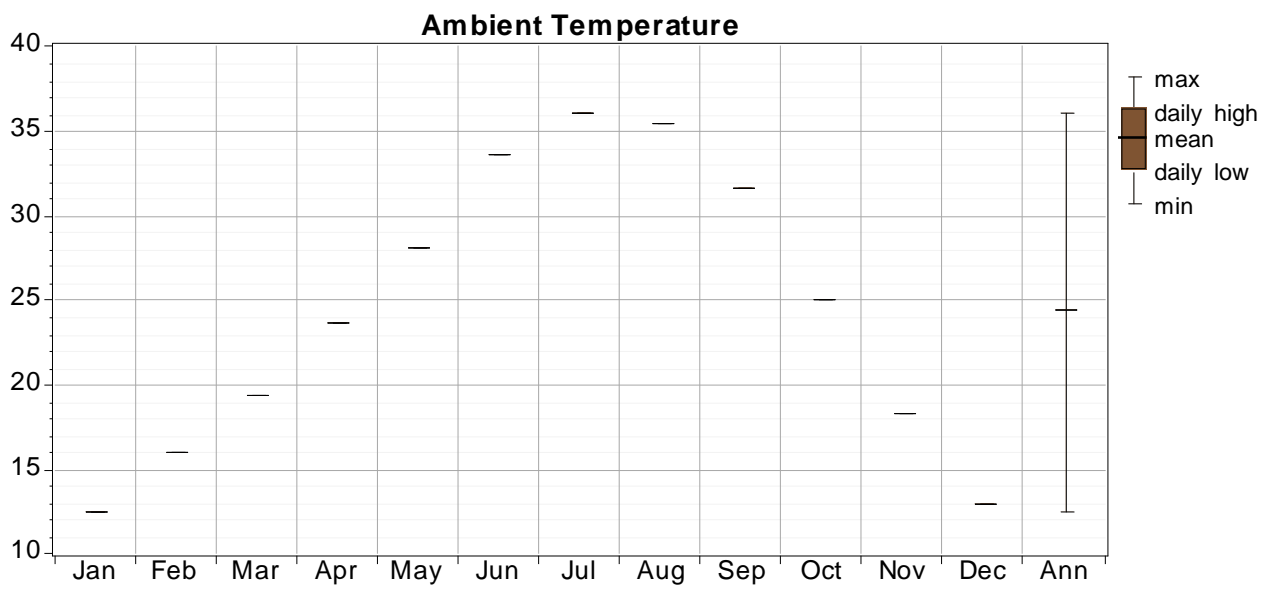

Figure 9: Annual average temperature $\left({ }^{\circ} \mathrm{C}\right)$. 


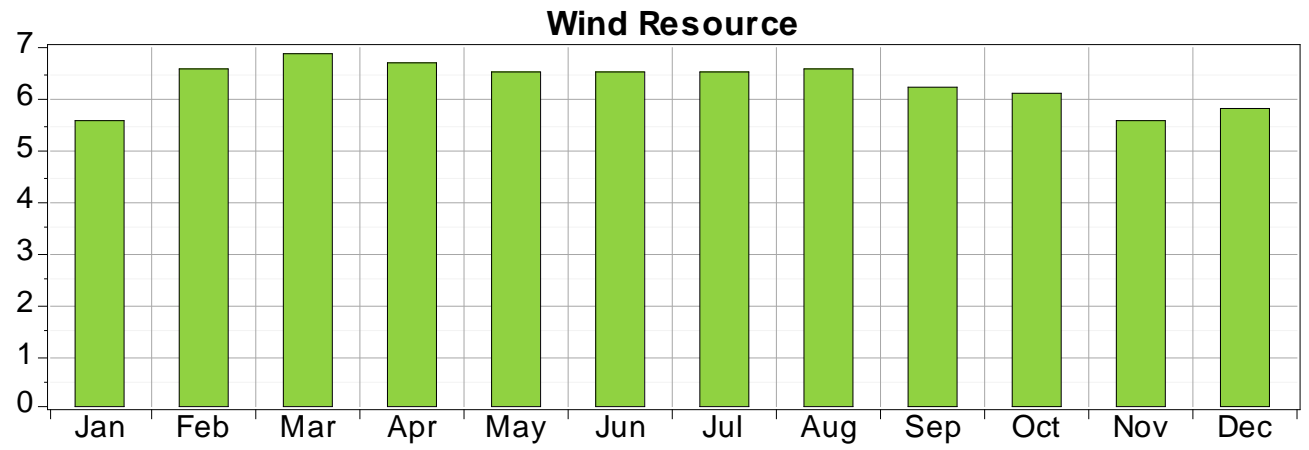

Figure 10: Average monthly wind speed data.

$(0.07 \$ / \mathrm{kWh})$, the optimization results of the system are summarized in Figure 11. In this case, a wind power system with engine generator seems to be most feasible economically with a minimum total net present cost (NPC) of $48,779 \$$ and a minimum cost of energy (COE) of $0.326 \$ / \mathrm{kWh}$. This is due to the abundant wind energy resource in Adrar. In addition, the COE of wind turbine generator is more economical than solar array modules.

Moreover, Figure 11 shows that when renewable fraction was $47 \%$ the NPC is $79.627 \$$ and the COE is
$0.533 \$ / \mathrm{kWh}$ which explain that the economic performance of the optimized photovoltaic-windgasoline generator system is lower in comparison to the same system without wind turbines.

The aim of this work is to show the economic and environmental effects of a system with $47 \%$ as renewable energy. Figure 12 shows the cost summary of each components of photovoltaic-wind-gasoline generator system. The PV panels used solely for the big charges is very expensive, which can be explained according to Figure $\mathbf{1 2}$ by their operational and

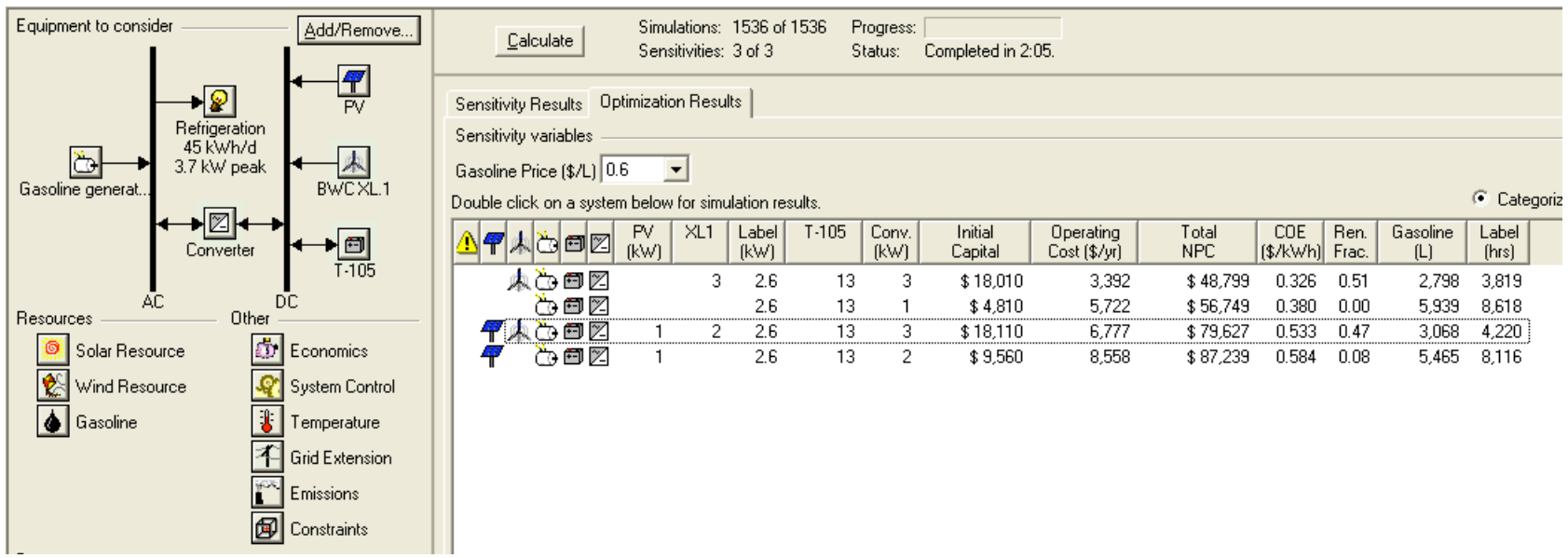

Figure 11: The optimization result of the HOMER simulation.

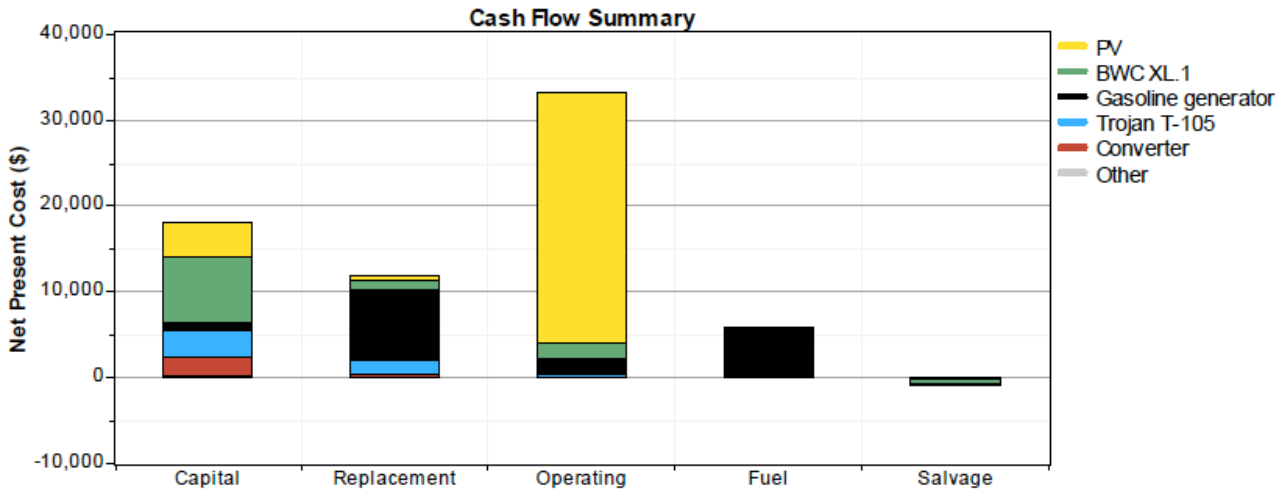

Figure 12: Cost summary of the HPS. 


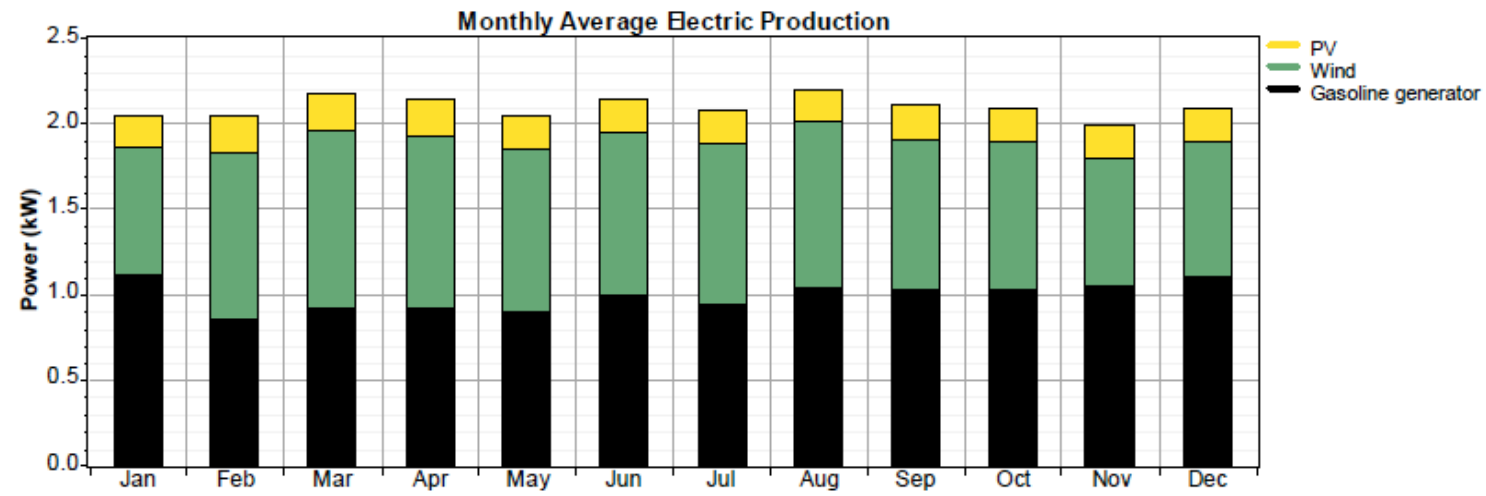

Figure 13: Monthly power generation.

Table 2: Comparison of Pollutant Emissions for the Optimum Systems

\begin{tabular}{|c|c|c|c|c|}
\hline \multirow{2}{*}{ Pollutant } & \multicolumn{2}{|c|}{ Emissions with renewable energy (kg/year) } & $\begin{array}{c}\text { Emissions without renewable } \\
\text { energy (kg/year) }\end{array}$ \\
\cline { 2 - 5 } & $\begin{array}{c}\text { PV-wind- Gasoline } \\
\text { generator }\end{array}$ & $\begin{array}{c}\text { Wind- Gasoline } \\
\text { generator }\end{array}$ & $\begin{array}{c}\text { PV- Gasoline } \\
\text { generator }\end{array}$ & Gasoline generator \\
\hline \hline Carbon dioxide & 7.460 & 8.419 & 12.872 & 13.799 \\
\hline Carbon monoxide & 20.9 & 23.6 & 36 & 38.6 \\
\hline Unburned hydrocarbons & 2.31 & 2.61 & 3.99 & 4.28 \\
\hline Particulate matter & 1.57 & 1.78 & 2.72 & 2.91 \\
\hline Sulfur dioxide & 15.3 & 17.3 & 26.5 & 28.4 \\
\hline Nitrogen oxides & 186 & 210 & 322 & 345 \\
\hline
\end{tabular}

maintenance $\mathrm{O} / \mathrm{M}$ costs in contrast to the wind turbines.

The monthly energy yield of each component of the photovoltaic-wind-gasoline system is shown in Figure 13. Implementing under the specific electricity load (16425 kWh/year), the photovoltaic array produces $9 \%$, and the wind turbine produces almost $43 \%$ and the Gasoline produces almost $47 \%$ of the system's total yearly energy production.

HOMER produces the amount of emissions of PVwind-generator system along with the amount of emissions summarized in the table below. The results reveal that the involvement of PV- wind turbine reduced the amount of emissions of different components.

Table 2 shows the emission with and without renewable energy production of the optimized system. As the main greenhouse gas, the emission of carbon dioxide from gasoline generator is $13.799 \mathrm{~kg} /$ year while the optimized system of $47 \%$ fraction of renewable energy exhausts only $7.460 \mathrm{~kg} / \mathrm{year}$, which means a 46 $\%$ reduction. Meanwhile, the sulfur dioxide and nitrogen oxide emissions of the wind-grid system are equal to less than $46 \%$ of a gasoline generator.

\section{CONCLUSION}

An attempt was made to explore the possibility of utilizing the power of the wind and the sun to reduce the dependence on fossil fuel for power generation to meet the energy requirement in term of refrigeration of a small house (e.g. a military base) located in the southern part of Algeria. The wind-pv-gasoline generator hybrid system with $47 \%$ renewable energy penetration ( $43 \%$ wind and $9 \%$ solar) and $47 \%$ diesel power contribution was found to be the most economical power system with COE of $0.533 \mathrm{US} \$ / \mathrm{kWh}$.

\section{REFERENCES}

[1] Weather station of The Renewable Energy Research Unit in Saharian Medium(URER/MS) Adrar, Algeria. http://www.urerms.dz/.

[2] Yang H, Zhou W, Lu L, Fang Z. Optimal sizing method for stand-alone hybrid solar-wind system with LPSP technology by using genetic algorithm. Sol Energ 2008; 82: 354. http://dx.doi.org/10.1016/j.solener.2007.08.005

[3] Barley CD. Optimal dispatch strategy in remote hybrid power systems. Sol Energ1996; 58: 165-79.

http://dx.doi.org/10.1016/S0038-092X(96)00087-4

[4] Bryne J, Shen B, Wallace B. The economics of sustainable energy for rural development: a study of renewable energy in China. Energ Policy 1998; 26: 45-54. http://dx.doi.org/10.1016/S0301-4215(97)00099-2 
[5] Celik AN. A simplified model for estimating yearly wind fraction. Renew Energ 2006; 31: 105-18.

http://dx.doi.org/10.1016/j.renene.2005.03.006

[6] Cavello AJ, Grubb AM. Renewable energy sources for fuels and electricity. London: Earthscan 1993.

[7] Saheb-Koussa D, Haddadi M, Maiouf Belhamel, Seddik H, Said N. Modelling and simulation of the fixed-speed WECS (wind energy conversion system): Application to the Algerian Sahara area. Energ 2010; 35: 4116-25. http://dx.doi.org/10.1016/j.energy.2010.06.032

[8] Ekren O, Ekren BY, Ozerdem B. Break-even analysis and size optimization of a PV/wind hybrid energy conversion system with battery storage - a case study. Appl Energ 2009; 86(7-8): 1043-54 http://dx.doi.org/10.1016/j.apenergy.2008.09.024

[9] Saheb-Koussa D, Haddadi M, Belhamel M. Economic and technical study of a hybrid system (wind-photovoltaic-diesel) for rural electrification in Algeria. Appl Energ 2009; 86: 102430.

http://dx.doi.org/10.1016/j.apenergy.2008.10.015

[10] Nfah EM, Ngundam JM, Tchinda R. Modelling of solar/diesel/battery hybrid power systems for far-north Cameroon. Renew Energ 2007; 32: 832-44. http://dx.doi.org/10.1016/j.renene.2006.03.010

[11] Sopian K, Ibrahim MZ, Daud WRW, Othman MY, Yatim B, Amin N. Performance of a PV-wind hybrid system for hydrogen production. Renew Energ 2009; 34: 1973-78. http://dx.doi.org/10.1016/j.renene.2008.12.010

[12] Arribas L, Cano L, Cruz I, Mata M, Llobet E. PV-wind hybrid system performance: A new approach and a case study. Renew Energ 2010; 35: 128-37. http://dx.doi.org/10.1016/j.renene.2009.07.002

[13] Jose L, Bernal-Agustın, Dufo-Lopez R. Techno-economical optimization of the production of hydrogen from PV-Wind systems connected to the electrical grid. Renew Energ 2010; 35: 747-58.

http://dx.doi.org/10.1016/j.renene.2009.10.004

[14] Mahmoudi H, Abdul-Wahab SA, Goosen MFA, et al. Weather data and analysis of hybrid photovoltaic-wind power generation systems adapted to a seawater greenhouse desalination unit designed for arid coastal countries. Des 2008; 222: 119-27.

http://dx.doi.org/10.1016/j.desal.2007.01.135

[15] Dufo-Lopez R, Jose L, Bernal-Agustın. Multi-objective design of PV- wind- diesel- hydrogen- battery systems. Renew Energ 2008; 33: 2559-72.
[16]

Tina G, Gagliano S, Raiti S. Hybrid solar/wind power system probabilistic modeling for long-term performance assessment. Sol Energ 2006; 80: 578. http://dx.doi.org/10.1016/j.solener.2005.03.013

[17] Shakya BD, Aye L, Musgrave P. Technical feasibility and financial analysis of hybrid wind-photovoltaic system with hydrogen storage for Cooma. Int J Hydrogen Energ 2005; 30: 9 .

http://dx.doi.org/10.1016/j.ijhydene.2004.03.013

[18] Kasbadji Merzouk N. Evaluation du gisement énergétique éolien contribution a la détermination du profil vertical de la vitesse du vent en Algérie. Thèse doctorat, Université Abou bekr Belkaid, Tlemcen 2006.

[19] Himri Y, Boudghene Stambouli A, Draoui B, Himri S. Technoeconomical study of hybrid power system for a remote village in Algeria.Energy 2008; 33: 1128-36.

http://dx.doi.org/10.1016/j.energy.2008.01.016

[20] Juhari Ab R, Kamaruzzaman S, Yusoff A, Mohammad Ahmed A, Azami Z, Ibrahim A. Optimization of PV-WindHydro-Diesel Hybrid System by Minimizing Excess Capacity. Eur J Sci Res 2009; 25: 663-71.

[21] Nayar CV, Phillips SJ, James WL, Pryor TL, Remmer D. Stand alone wind/diesel/battery hybrid energy systems. Sol Energ 1997; 21: 13-19.

[22] Fortunato B, Mummolo G, Cavallera G. Economic optimisation of a windpowerplant for isolated locations. Sol Energ 1997; 60: 347-58. http://dx.doi.org/10.1016/S0038-092X(97)00027-3

[23] Rehman S. Prospects of Wind Farm Development in Saud Arabia. Renew Energ 2004; 30: 447-63. http://dx.doi.org/10.1016/j.renene.2004.04.008

[24] Rehman S, Aftab A. Assessment of Wind Energy Potential for Coastal Locations of the Kingdom Saudi Arabia. Energ 2004; 29: 1105-15.

http://dx.doi.org/10.1016/j.energy.2004.02.026

[25] HOMER 2.14 National Renewable Energy Laboratory (NREL), 617 Cole Boulevard, Golden, CO 80401-3393, URL: http://www.nrel.gov/homer.

[26] El-Hefnawi SH. Photovoltaic diesel-generator hybrid power system sizing. Renew Energ 1998; 13: 33-40. http://dx.doi.org/10.1016/S0960-1481(97)00074-8

[27] Kasbadji Merzouk N, Wind energy potential of Algeria. Renew Energ 2000; 21: 553-62. http://dx.doi.org/10.1016/S0960-1481(00)00090-2 